\title{
RANCANG BANGUN CLOSED CIRCUIT TELEVISION SECARA NIRKABEL MENGGUNAKAN ZIGBEE 2,4GHZ
}

\author{
Dwi Wahyu Irawan ${ }^{1}$, Faqih Rofii ${ }^{2}$, Anis Qustoniah ${ }^{3}$ \\ ${ }^{1}$ Fakultas Teknik, Jurusan Teknik Elektro, Universitas Widyagama Malang \\ ${ }^{2}$ Fakultas Teknik, Jurusan Teknik Elektro, Universitas Widyagama Malang \\ ${ }^{3}$ Fakultas Teknik, Jurusan Teknik Elektro, Universitas Widyagama Malang \\ Email: wannurs.scorpio8792@gmail.com
}

\begin{abstract}
Abstrak
Closed Circuit Television (CCTV) merupakan sistem keamanan yang popular untuk digunakan sebagai kamera pengawas. Salah kelemahan pada CCTV adalah media transmisi video yang masih menggunakan kabel dan perekaman gambar yang masih manual. Sistem pemantau video secara nirkabel merupakan perpaduan beberapa komponen, berupa Zigbee/Xbee yang merupakan komponen komunikasi data nirkabel, sensor gerak Passive Infra Red (PIR) sebagai pendeketeksi gerakan, dan Arduino MEGA2560 yang berfungsi sebagai perangkat yang menghubungkan antara pengguna dan jaringan Zigbee/Xbee dan terhubung dengan perangkat lunak pada PC sehingga dapat melakukan pengiriman data secara nirkabel dan dapat merekam data secara otomatis jika ada gerakan yang terdeteksi.
\end{abstract}

Kata kunci: CCTV, PIR, Zigbee/Xbee, WSN.

\begin{abstract}
Close Circuit Television (CCTV) is a popular security system using surveillance cameras. But at the moment it still has several weaknesses, including the video transmission media still using cables and image recording methods that still use the manual method. The wireless video monitoring system is a combination of several components, in the form of Zigbee/Xbee which is a component of wireless data communication, PIR (Passive Infra Red) motion sensor as a motion detection device, and Arduino MEGA2560 which functions as a device that connects Zigbee/Xbee users and networks. Connected with software on the PC so that it can transmit data wirelessly and can record data automatically if any motion is detected.
\end{abstract}

Keywords: CCTV, PIR, Zigbee / Xbee, WSN. 


\section{PENDAHULUAN}

Perkembangan Teknologi Komunikasi wireless sekarang sangat pesat dalam beberapa tahun ini, disebabkan komunikasi wireless sangat efisien. Salah satu teknologi komunikasi wireless yang banyak diminati adalah WPANs (Wireless Personal Area Networks) [1]. Salah satu teknologi WPANs yang banyak digunakan untuk komunikasi antar perangkat adalah Zigbee. Zigbee merupakan perangkat komunikasi tingkat tinggi, dengan speksifikasi IEEE 802.15.4 serta memiliki konsumsi daya rendah dan bekerja pada fekuensi $2,4 \mathrm{GHz}$ [2]. Sistem keamanan menggunakan kamera pengawas Close Circuit Television (CCTV) dapat mengungkap berbagai bentuk kejahatan dengan bantuan CCTV tersebut, tetapi CCTV konfensional yang ada dipasaran untuk melakukan komunikasi hanya melalui kabel yang terkoneksi dengan computer tanpa adanya sensor tambahan [3].

WSN (Wireless Sensor Network) adalah suatu jaringan komunikasi sensor yang terhubung secara wireless untuk memonitor kondisi fisis atau kondisi lingkungan tertentu pada lokasi yang berbeda antara sensor dan pemrosesan datanya. WSN ini dapat diterapkan sebagai topologi jaringan CCTV nirkabel [4].

Oleh karena itu di perlukannya suatu system monitoring video berbasis wireless sensor network menggunakan komunikasi Zigbee 2,4 GHz, dengan perangkat keras dan perangkat lunak yang dapat merekam dengan sendirinya jika ada pergerakan objek dan pengiriman data melalui wireless.

\section{STUDI PUSTAKA}

\subsection{Komunikasi Nirkabel}

Sistem Komunikasi Nirkabel adalah sistem komunikasi tanpa kabel. Merupakan sistem komunikasi yang berkembang dengan pesat seiring dengan permintaan pelanggan. Sistem komunikasi ini memiliki dua arsitektur yaitu Point to Point (PTP) dan Point to Multipoint (PTMP) [1].

Point to Point (PTP) dikenal juga dengan nama leased lines, yaitu merupakan komunikasi antara dua lokasi misalnya komunikasi antar sebuah kantor cabang dengan kantor perwakilan dalam satu daerah seperti terlihat pada Gambar 2.1 dibawah:
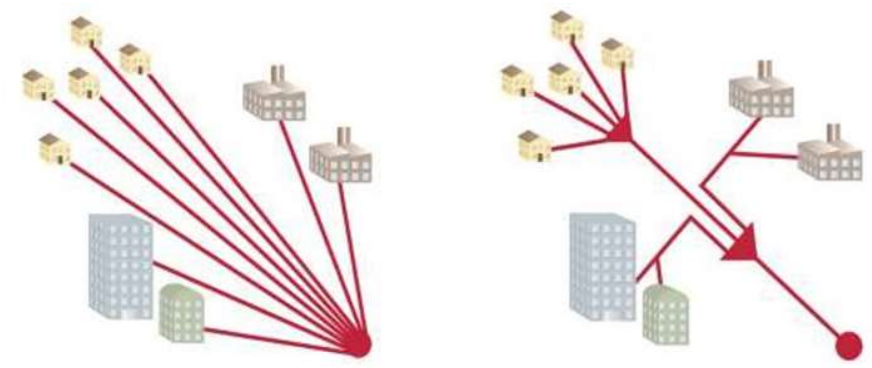

Gambar 2.1 Arsitektur Point to Point dan Point to Multipoint

\subsection{Diagram Blok Sistem Komunikasi Nirkabel}

Proses perancangan untuk sistem komunikasi pita lebar nirkabel membutuhkan suatu perencanaan yang rumit dan perhitungan untuk memprediksi kinerja dari sistem itu sendiri sebelum dibangun. Semua sistem komunikasi nirkabel dapat digambarkan melalui diagram blok dasar yang ditunjukkan oleh Gambar 2.2 dibawah. 


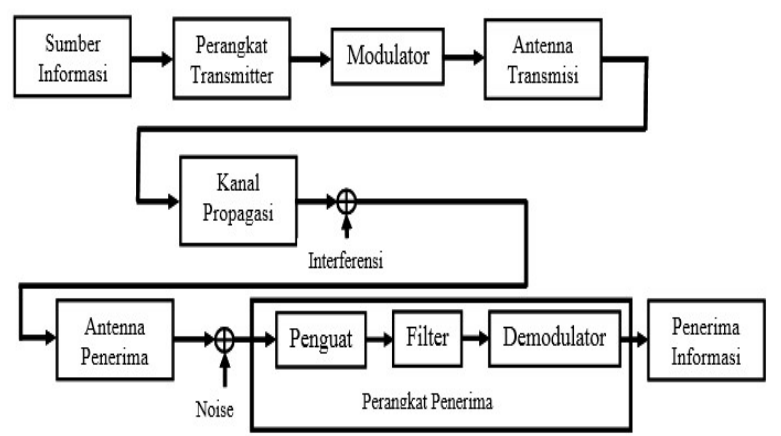

\section{Gambar 2.2 Diagram Blok Dasar Sistem Komunikasi Nirkabel}

\subsection{Standar IEEE 802.11}

IEEE 802.11 working group adalah bagian dari IEEE 802 LAN/MAN Standar Committe (LMSC), yang beroperasi dibawah naungan IEEE, yaitu perusahaan professional terbesar didunia. Standar asli IEEE 802.11 disediakan untuk jaringan nirkabel pada band ISM yang menyediakan kecepatan data 1-2 Mbps. Kecepatan ini tentunya kurang dari jaringan Ethernet yang biasanya bekerja pada 10 sampai 100 Mbps dan dapat dikembangkan dengan biaya peralatan yang murah [5].

\subsection{Wireless Sensor Network (WSN)}

Wireless Sensor Network (WSN) adalah Jaringan komunikasi sensor yang terhubung secara Wireless untuk memonitor kondisi fisik fisis atau kondisi lingkungan tertentu pada lokasi yang berbeda antara sensor dan proses datanya [4].

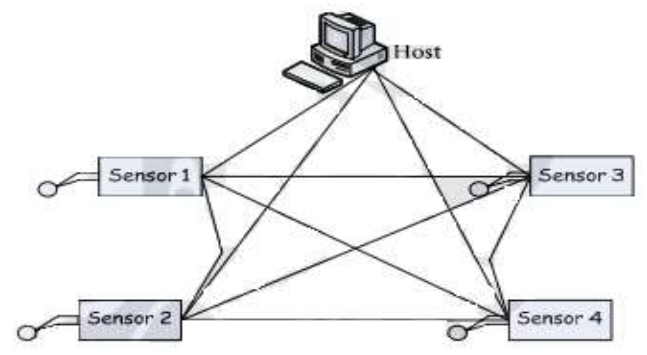

Gambar 2.5 Topologi WSN

\subsection{Teknologi ZigBee}

\subsubsection{Zigbee}

Zigbee termasuk standard keluarga 802.15. Zigbee mempunyai kode standard 802.15.4. Kecepatan maksimal dari zigbee adalah $250 \mathrm{Kbps}$ dan jarak maksimal yang dapat dijangkau adalah \pm 100 meter [2].

\subsubsection{Zigbee XBee Pro}

XBee-PRO merupakan modul RF (Radio Frekuensi) yang beroperasi pada frekuensi $2.4 \mathrm{GHz}$ dan merupakan salah satu modul dengan komunikasi zigbee.

Radio frequency tranciever atau pengirim dan penerima frequensi radio ini berfungsi untuk komunikasi secara full duplex. 


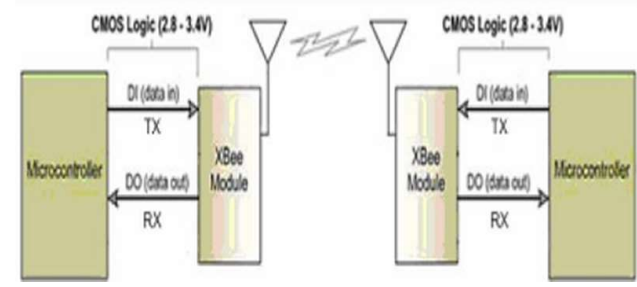

Gambar 2.6 Ilustrasi prinsip kerja modul Xbee

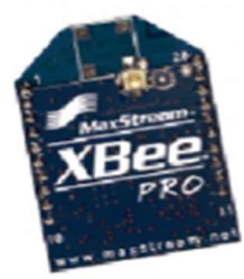

Gambar 2.7 Modul XBee Pro

\subsection{Twig-Serial Camera}

Twig serial camera merupakan piranti kamera elektronik pencuplik gambar menggunakan komunikasi serial. Adapun gambar yang dihasilkan dari proses pencuplikan adalah JPEG dengan reolusi yang dapat dipilih yaitu 320x240 atau $640 \times 480$ [6]. Adapun bentuk fisik dari TWIG serial camera V9.0 ditunjukkan pada gambar di bawah ini:
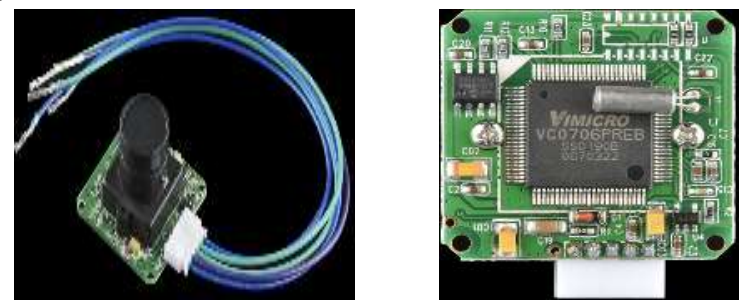

Gambar 2.8 Bentuk TWIG Serial Camera Tampak Atas dan Tampak Bawah.

\subsection{Arduino MEGA 2560}

Arduino Mega 2560 adalah merupakan board mikrokontroler berbasis ATMega2560. Adapun bentuk fisik dari modul Arduino MEGA 2560 ditunjukkan pada gambar berikut:

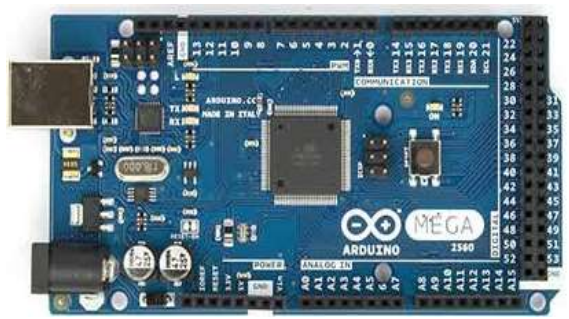

Gambar 2.9 Board Arduino MEGA 2560

Board Arduino mega 2560 menggnakan mikrokontroller Atmega2560 sebagai basis processornya dengan kofisgurasi pin yang dipetakan sebagaimana 161able dan gambar berikut: 


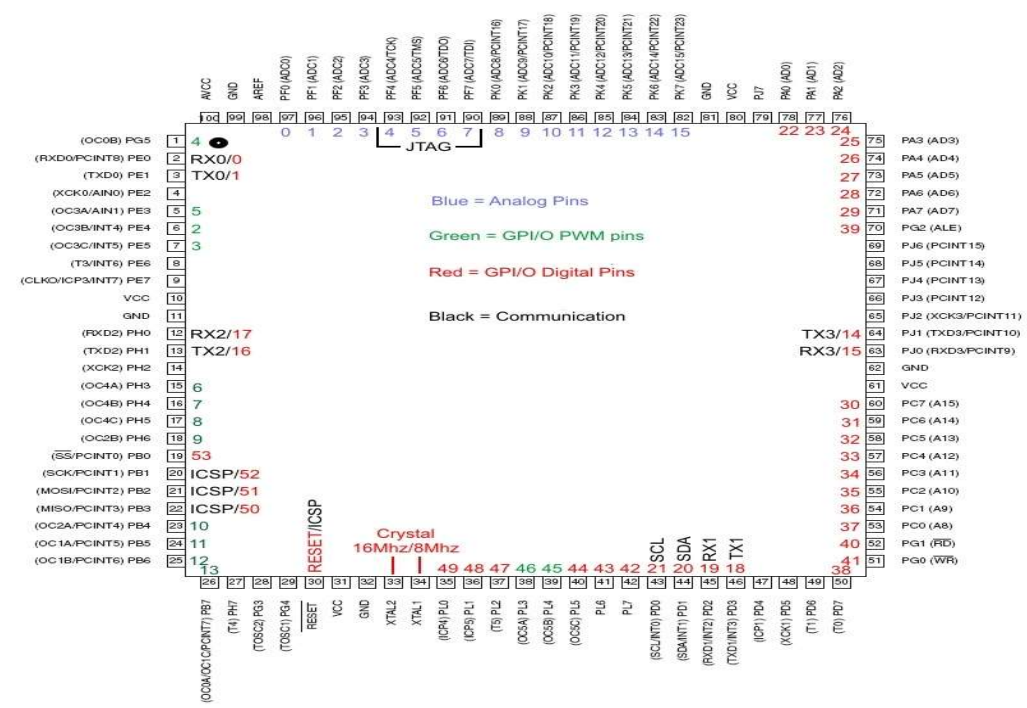

Gambar 2.10 Kofigurasi pin ATMEGA2560 pada Arduino mega2560

\subsection{Sensor Gerak PIR (Passive Infra Red)}

Sensor gerak Passive Infra Red dapat mendeteksi adanya gelombang infra merah yang dipancarkan oleh manusia. Sensor PIR sensitiv terhadap perubahan temperature dan untuk mencegah perubahan temperature lingkungan yang cepat, rangsangan kuat atau getaran.

\section{METODE}

\subsection{Blok Diagram Sistem}

Blok diagram system pada perancangan ini terdiri dari 2 sistem yang meliputi bagian pemancar dan penerima.

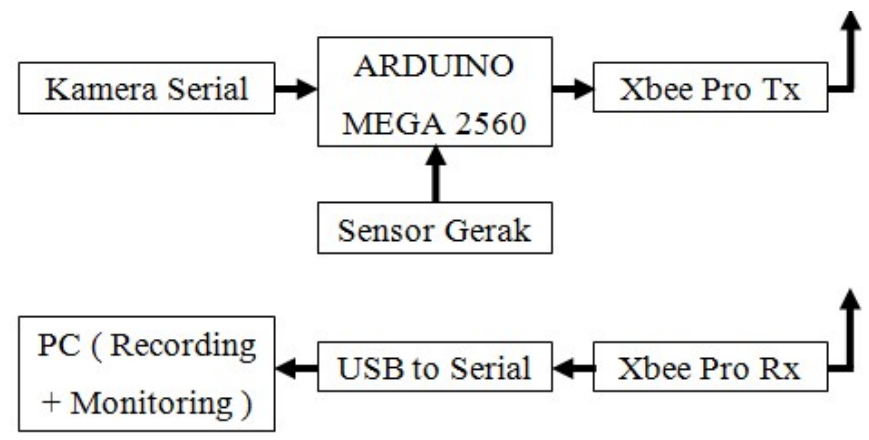

Gambar 3.1 Blok Diagram Sistem

Sistem pemancar terdiri dari pengontrol utama ARDUINO MEGA2560 pada board arduino mega2560 yang bertugas membaca output dari sensor gerak, menangani data serial dari kamera serial dan data serial wireless Xbee pro 2,4Ghz. Berdasarkan cara kerjanya yaitu saat ada gerakan yang terdeteksi oleh sensor gerak, maka sensor akan memberikan informasi pada mikrokontroller ARDUINO MEGA2560, sehingga pada kondisi ini mikrokontroller dapat mengetahui adanya gerakan, selanjutnya melakukan komunikasi pada camera serial untuk mulai 
melakukan pencuplikan gambar kamera serta mengirimkan data hasil cuplikan gambar kamera tersebut melalui wireless Xbee dengan kecepatan data $115200 \mathrm{bps}$. Alasan utama menggunakan ARDUINO MEGA2560 karena pada sistem terdiri dari 2 buah serial yaitu dari kamera dan Xbee, sehingga mikrokontroler yang cocok digunakan adalah ARDUINO MEGA2560 yang mempunyai fitur dual UART.

Pada bagian penerima terdiri dari Xbee pro, USB to Serial dan PC yang berfungsi menampilkan gambar hasil pemantauan kamera pada bagian pengirim melalui komunikasi data serial dengan kecepatan 115200bps. Modul Xbee yang berfungsi membaca hasil pengiriman data serial informasi video yang dikirimkan dari pemancar selanjutnya mengirimkan data tersebut ke PC melewati USB to serial converter agar data tersebut dapat diolah menjadi video pada perangkat lunak PC.

\subsection{Perancangan perangkat Keras}

\subsubsection{Perancangan kamera}

Pada perancangan ini kamera yang digunakan adalah LINKSPRITE serial camera yang di desain khusus untuk mengcapture gambar kwalitas JPEG dengan resolusi $640 \times 480$ / 320x240 dan menggunakan komunikasi serial UART dengan baud rate 115200 bps.

\subsubsection{Perancangan Sensor Gerak}

Dalam perencanaan sensor gerak ini menggunakan PIR (Passive Infra Red) yang dapat mendeteksi adanya gelombang infra merah yang dipancarkan oleh manusia. Proses kerja sensor ini dilakukan dengan mendeteksi adanya radiasi panas tubuh manusia yang diubah menjadi perubahan tegangan. Adapun perancangan rangkaian sensor infrared $\mathrm{KC} 778 \mathrm{~B}$ terhadap mikrokontroller ditunjukkan sebagaimana gambar 3.4:

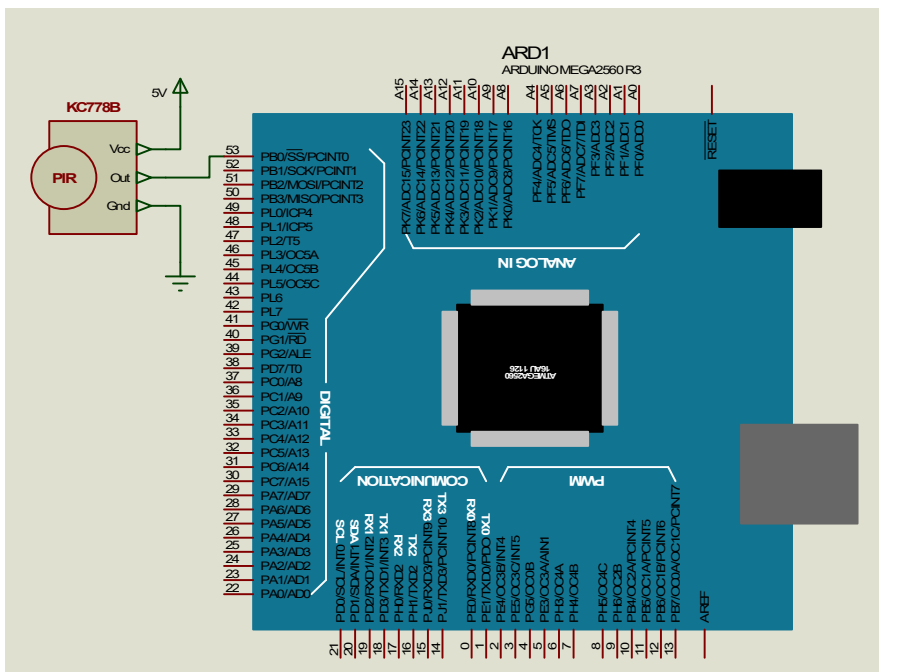

Gambar 3.4 Rangkaian Sensor Gerak (PIR) pada arduino

\subsubsection{Perancangan rangkaian Xbee Zigbee S2B}

Agar modul arduino dapat berkomunikasi secara serial wireless dengan perangkat lain, maka dibutuhkan rangkaian wireless yang dalam perancangan ini 
menggunakan modul Zigbee S2B. Modul zigbee dapat berkomunikasi wireless dan diakses menggunakan komunikasi serial TTL. Adapun port serial yang digunakan untuk pengendalian dan pembacaan modul Xbee adalah TXO dan RX0 pada modul arduino sebagaimana ditunjukkan pada gambar 3.5:

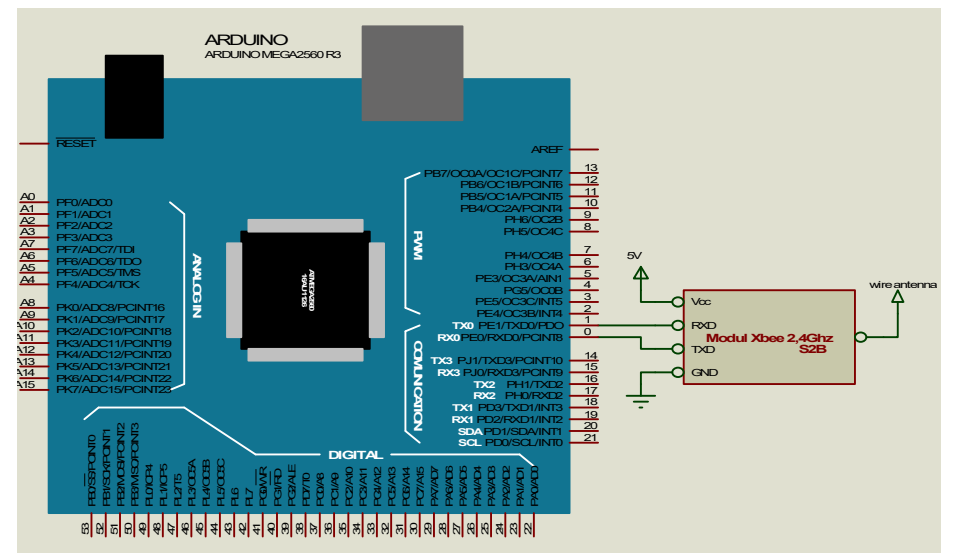

Gambar 3.5 Hubungan Rangkaian Xbee dan arduino

\subsubsection{Perancangan rangkaian USB to serial Xbee}

Untuk dapat menerima data serial hasil pengiriman dari mode1 dan 2 atau perangkat wireless Xbee pengirim, maka pada bagian penerima juga dibutuhkan xbee. USB to serial Xbee yang difungsikan khusus untuk menjembatani antarmuka UART antara komputer dengan Xbee. Adapun rangkaian modul USB to serial Xbee ditunjukkan pada gambar 3.4:

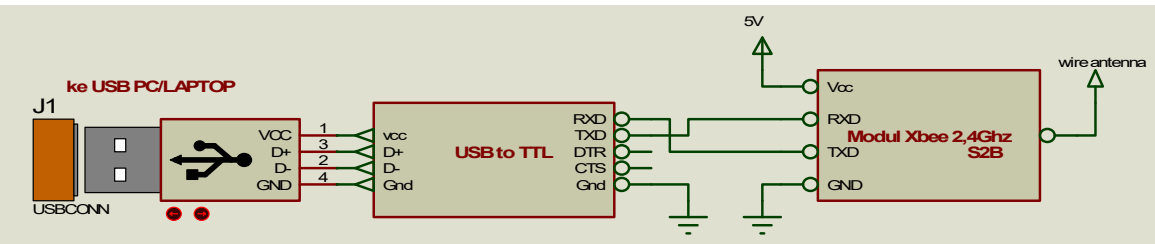

Gambar 3.6 Rangkaian modul USB to serial Xbee pada base station

Sementara itu bentuk fisik dari modul USB to serial Xbee ditunjukkan pada gambar 3.7

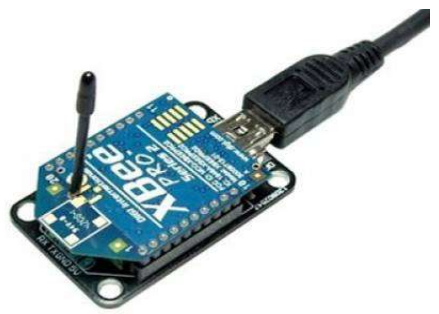

Gambar 3.7 Modul USB to serial Xbee

\subsection{Flow chart keseluruhan}

Adapun perancangan perangkat lunak keseluruhan pada sistem ditunjukkan pda gambar di bawah ini: 


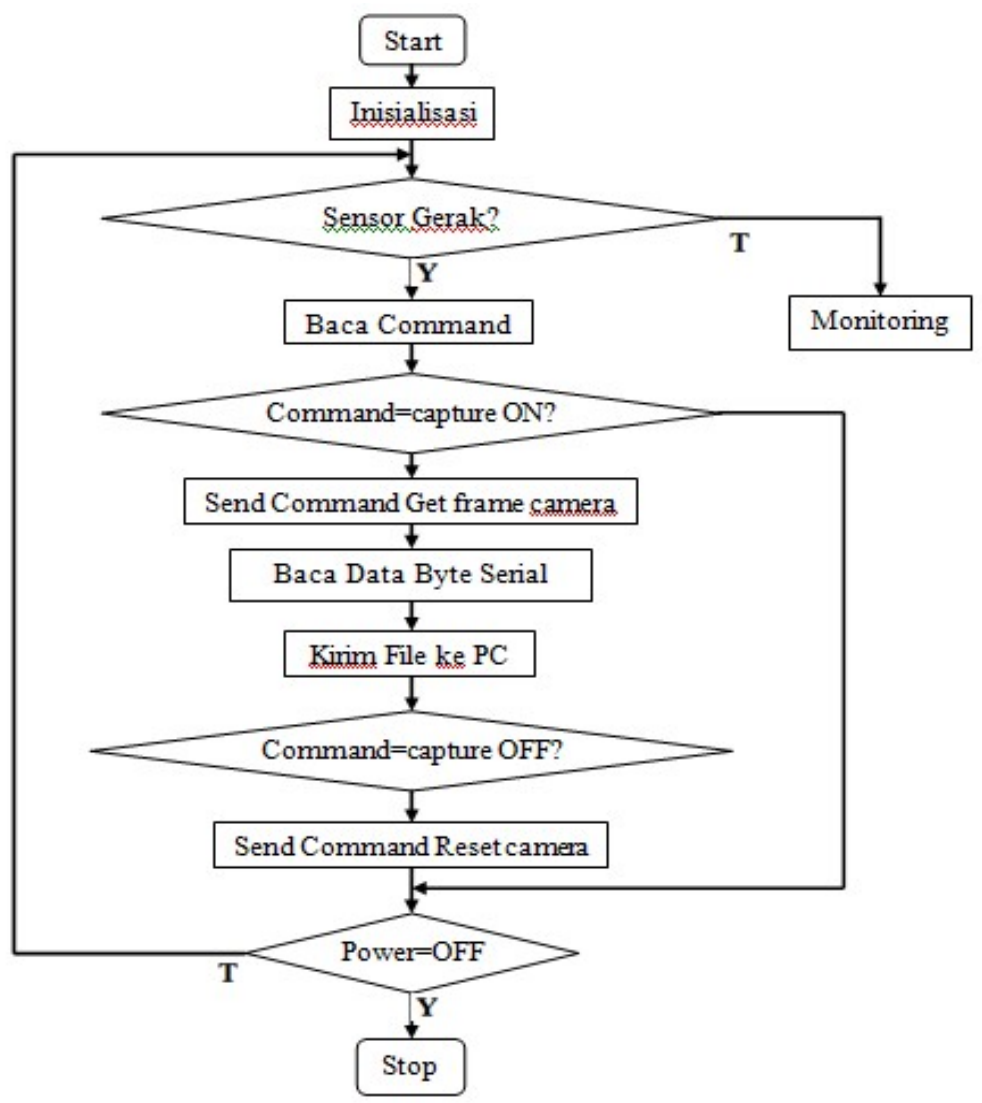

Gambar 3.8 Flowchart Keseluruhan

\section{HASIL DAN PEMBAHASAN}

Pengujian Alat terdiri pengujian dari masing masing bagian dari rancangan blok diagram untuk memastikan kinerja dan hasil dari masing - masing perangkat, baik perangkat keras dan perangkat lunak. Untuk itu pada bagian ini akan dibahas pengujian dari bagian pendukung sistem maupun sistem secara keseluruhan untuk mengetahui spesifikasi dan kinerja dari alat yang telah dirancang. Adapun pengujian dari masing - masing bagian pada sistem diuraikan sebagaiamana pembahasan pada pengujian berikut:

\subsection{Pengujian Minimum sistem ARDUINO MEGA2560}

\subsubsection{Tujuan Pengukuran}

Untuk mengetahui bekerja tidaknya modul arduino dalam mengksekusi program.

\subsubsection{Peralatan Yang digunakan}

1. Power Supply

2. Modul Arduino MEGA2560 dan software.

\subsubsection{Langkah-langkah pengukuran:}

1. Download software uji LED pada modul Arduino. 
2. Nyalakan power suplay

3. Perhatikan hasil pada LED

\subsubsection{Pengujian Rangkaian}

Pada pengujian ini modul arduino MEGA2560 diisi program untuk menyalakan LED berkedip untuk mengetahui bekerja tidaknya modul yang diisi melalui formware arduino. Adapun LED terhubung pada pin 13 sesuai bawaan modul arduino MEGA2560 dengan rangkaian sebagaimana ditunjukkan pada gambar 4.1

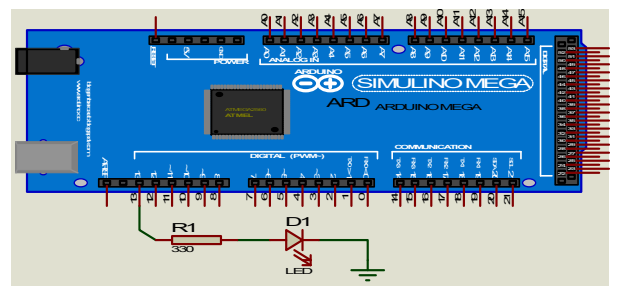

Gambar 4.1 Rangkaian Pengujian Minimum Sistem Arduino MEGA2560

\subsubsection{Hasil Pengujian}

Dari hasil pengujian LED ditunjukkan dalam Gambar 4.2 berikut:

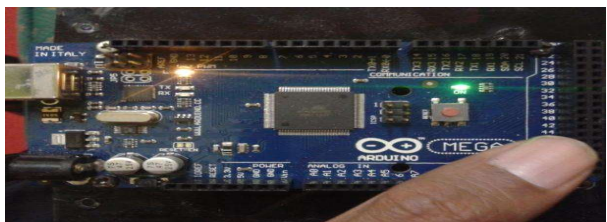

Gambar 4.2 Hasil Pengujian Minimum Sistem Arduino MEGA2560

\subsubsection{Analisa}

Pada saat AVR dinyalakan, maka program akan mulai melakukan inisialisasi port, dimana pada program, inisialisasi dilakukan dengan mengaktifkan pin 13 sebagai pin output, selanjutnya pada routing loop, LED dinyalakan dengan perintah digitalWrite(led, HIGH); kemudian tunda 1 detik dan dilanjutkan dengan perintah digital Write (led, LOW); untuk mematikan LED. Dari hasil pengamatan, LED menyala dan mati bergantian selama 1 detik sesuai dengan alur program.

\subsection{Pengujian Converter USB to SERIAL TTL pada Xbee Converter.}

\subsubsection{Tujuan}

Untuk mengetahui apakah modul konverter serial Xbee berfungsi dengan baik atau tidak dalam mengirimkan data serial.

\subsubsection{Alat dan bahan}

1. Rangkaian modul Konverter USB to TTL Xbee type CP2102

2. Software Serial atau Hyper terminal

3. Komputer

\subsubsection{Prosedure pengujian}

1. Hubungkan pin serial RX dengan pin TX pada USB TTL Converter (loop back). 
2. Jalankan program Hyperterminal pada PC

3. Amati dan dan catat hasil pengiriman data serial.

\subsubsection{Diagram pengujian}

Adapun diagram rangkaian yang digunkan dalam pengujian mengacu pada gambar 4.3:

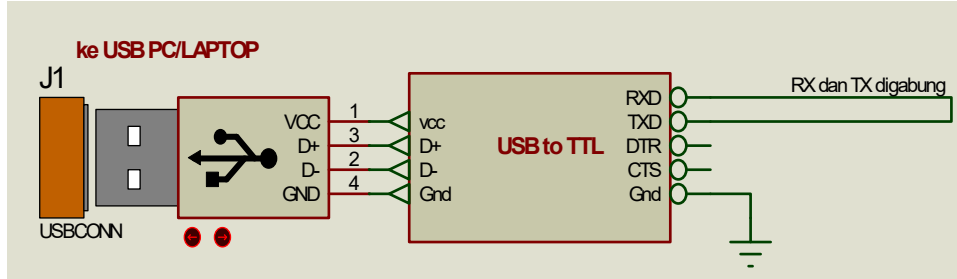

Gambar 4.3 Diagram Pengujian Converter USB to TTL

\subsection{Pengujian sensor gerak PIR (Passive Infrared)}

\subsubsection{Tujuan Pengukuran}

Mengetahui perubahan tegangan keluaran sensor terhadap adanya gerakan yang diterima didepan sensor.

\subsubsection{Peralatan Yang Digunakan}

1. Power Supply

2. Avometer analog / digital

3. Rangkaian sensor gerak PIR type KC776.

\subsubsection{Langkah-Langkah Pengukuran}

1. Hubungkan power suplay pada sensor

2. Hubungkan output sensor pada avometer

3. Nyalakan Power suplay

4. Uji sensor dengan memberika gerakan didepan sensor.

\subsection{Diagram Pengujian}

Blok diagram pengujian sensor gerak PIR ditunjukkan pada Gambar 4.4:

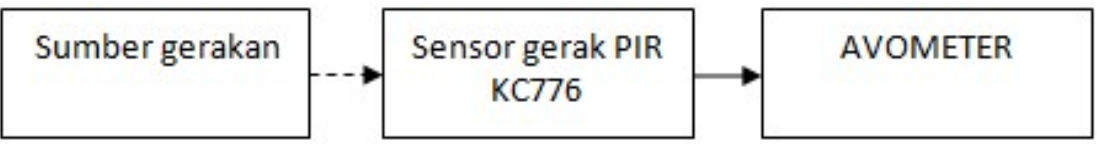

Gambar 4.4 Diagram Pengujian Sensor

\subsubsection{Data Hasil Pengukuran}

Pada pengujian ini sensor PIR diuji dengan memberikan gerakan tangan didepan permukaan sensor dan didapat haisl pengujian sebagaimana ditunjukkan pada Gambar 4.5: 


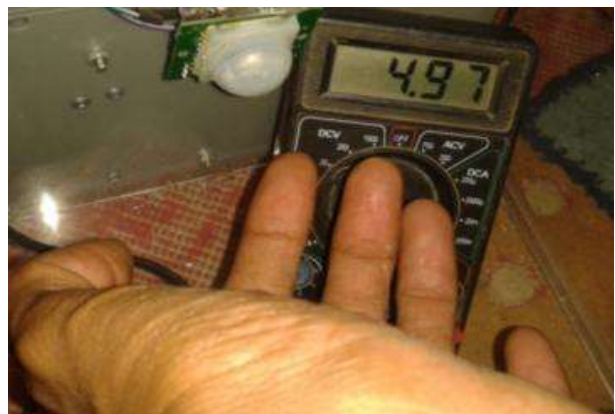

\section{Gambar 4.5 Hasil Pengujian Sensor Gerak dengan Memberikan Gerakan Tangan}

Radius jarak yang mampu dipantau oleh permukaan sensor berdasarkan datasheet adalah berkisar \pm 5 meter. Sementara itu pengujian berdasarkan jarak jangkauan PIR ditunjukkan pada tabel 4.1 berikut:

Tabel 4.1 Pengujian sensor gerak

\begin{tabular}{|l|l|}
\hline Jarak gerakan & \multicolumn{1}{|c|}{ Output sensor } \\
\hline $1 \mathrm{~m}$ & 1 (deteksi) \\
\hline $2 \mathrm{~m}$ & 1 (deteksi) \\
\hline $2,5 \mathrm{~m}$ & 1 (deteksi) \\
\hline $4 \mathrm{~m}$ & 1 (deteksi) \\
\hline $4,5 \mathrm{~m}$ & 1 (deteksi) \\
\hline $5 \mathrm{~m}$ & 0 (tidak deteksi) \\
\hline $5,5 \mathrm{~m}$ & 0 (tidak deteksi) \\
\hline $6 \mathrm{~m}$ & 0 (tidak deteksi) \\
\hline
\end{tabular}

\subsubsection{Analisa}

Sensor PIR KC776 merupakan modul sensor gerak yang telah terintegrasi dengan controller didalamnya yang mana output yang dihasilkan akan berlogika 1 (high) pada saat ada gerakan, sementara saat tidak ada gerakan, output yang diterima berlogika 0. Pada pengujian ini saat tangan digerakkan didepan permukaan sensor, maka sensor merespon adanya gerakan.

Sementara dalam pengujian terhadap jarak jangkaun, sensor PIR hanya mampu mendeteksi maksimal $\pm 4,5$ meter.

\subsection{Pengujian perangat kamera pada Delphi}

Tabel 4.2 Pengukuran saat siang hari

\begin{tabular}{|c|c|c|c|c|}
\hline \multicolumn{5}{|c|}{ PENGUKURAN SAAT SIANG HARI } \\
\hline No. & Jarak (meter) & Hasil Pengukuran & Pergerakan & Waktu \\
\hline $\mathbf{1}$ & $0 \mathrm{~m}$ & $255 \mathrm{Lux}$ & Gerakan OFF & 00.00 \\
\hline $\mathbf{2}$ & $1 \mathrm{~m}$ & $208 \mathrm{Lux}$ & Gerakan ON & 30.84 \\
\hline $\mathbf{3}$ & $3 \mathrm{~m}$ & $181 \mathrm{Lux}$ & Gerakan ON & 32.32 \\
\hline $\mathbf{4}$ & $6 \mathrm{~m}$ & $148 \mathrm{Lux}$ & Gerakan OFF & 00.00 \\
\hline
\end{tabular}




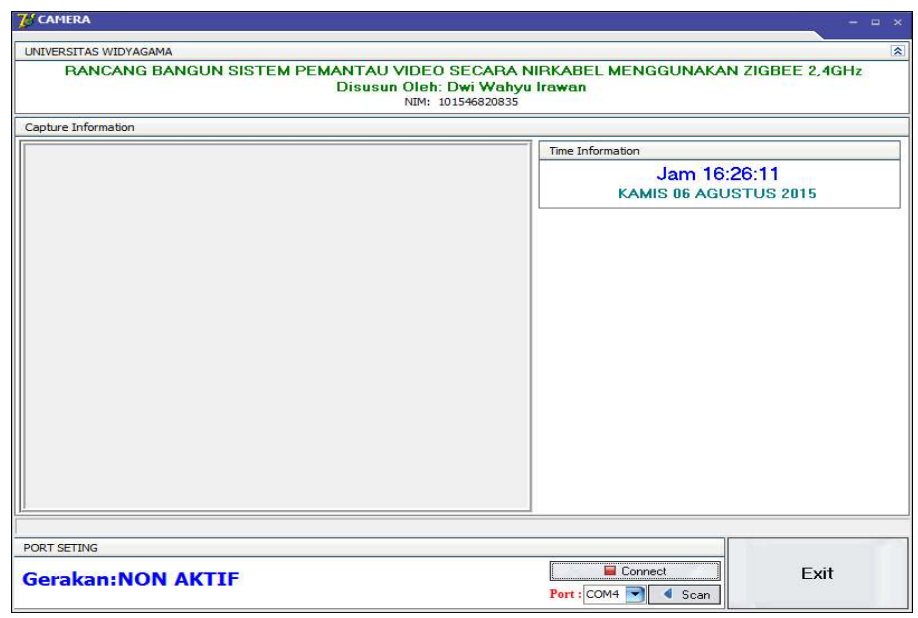

Gambar 4.6 Jarak 0 Meter pada pengukuran 255 Lux dengan waktu 00.00 detik tanpa adanya pergerakan

\subsection{Hasil Pengujian Alat}

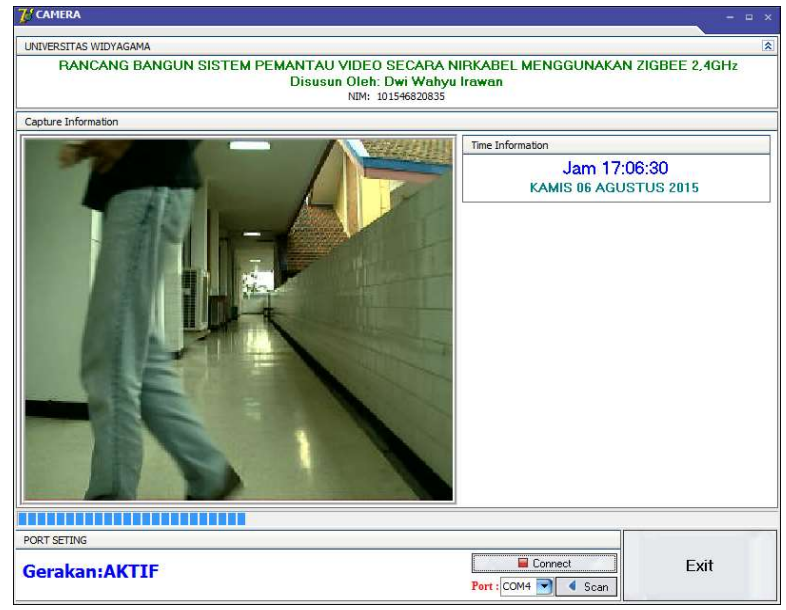

Gambar 4.7 Jarak 1 Meter pada pengukuran 208 Lux dengan waktu 30.84 detik adanya pergerakan.

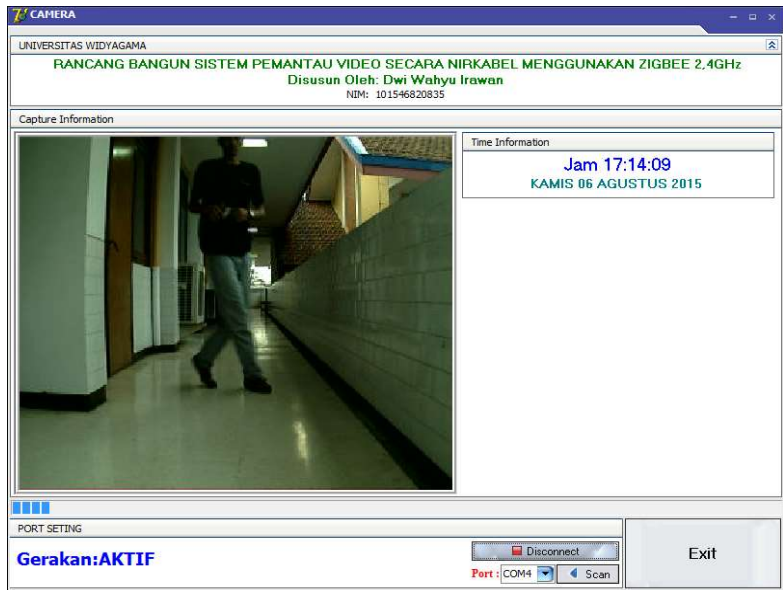

Gambar 4.8 Jarak 3 Meter pada pengukuran 181 Lux dengan waktu 32.52 detik adanya pergerakan. 


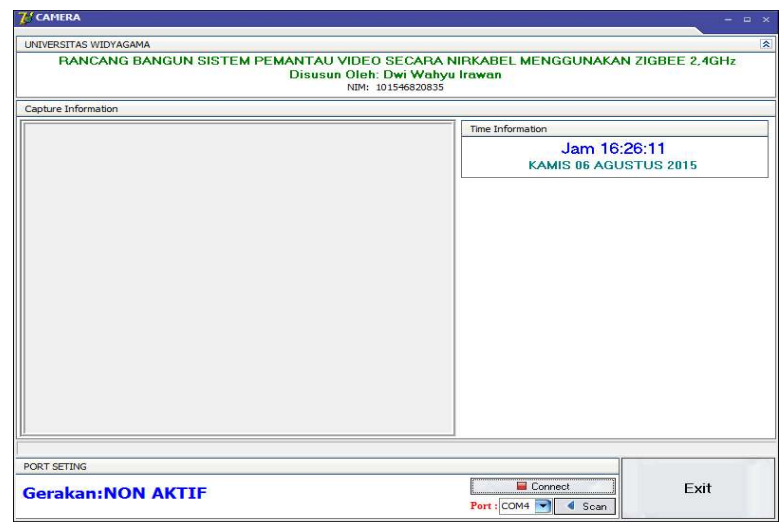

Gambar 4.9 Jarak 6 Meter pada pengukuran 148 Lux dengan waktu 00.00 detik tanpa adanya pergerakan.

\section{KESIMPULAN}

Berdasarkan analisa hasil pengujian yang telah dilakukan maka dapat diambil kesimpulan sebagai berikut:

1) Modul Xbee pada sistem mampu melakukan komunikasi data serial secara nirkabel dengan pengalamatan dan bekerja pada kecepatan 115200 bps degan jangkauan bebas halangan sekitar 100mter dan 40meter untuk kondisi terhalang.

2) Senosr PIR yang dirancang dapat melakukan pengindraan gerakan manusia dengan jangkauan \pm 5 meter.

3) Perangkat lunak PC yang dirancang dapat melakukan oleh data serial dan menampilkan gambar JPEG serta menyimpan gambar hasil kiriman data dari perangkat arduino dan camera

\section{DAFTAR RUJUKAN}

[1] R. Riyanto, "Analisis Dan Perancangan Keamanan Jaringan Kabel Dan Nirkabel Pada Kantor Imigrasi Kelas II Kabupaten Karawang," PhD Thesis, Universitas Muhammadiyah Surakarta, 2013.

[2] Z. Alliance, "What is Zigbee?," 2015.

[3] R. Armitage, "To CCTV or not to CCTV," Rev. Curr. Res. Eff. CCTV Syst. Reducing Crime, p. 8, 2002.

[4] I. F. Akyildiz, W. Su, Y. Sankarasubramaniam, and E. Cayirci, "Wireless Sensor Networks: a survey," Comput. Netw., vol. 38, no. 4, pp. 393-422, 2002.

[5] G. Bianchi, "Performance Analysis of The IEEE 802.11 Distributed Coordination Function,” IEEE J. Sel. Areas Commun., vol. 18, no. 3, pp. 535-547, 2000.

[6] S. Budijono, J. Andrianto, and M. A. N. Noor, "Design and Implementation Of Modular Home Security System With Short Messaging System," in EPJ Web of Conferences, 2014, vol. 68, p. 00025. 